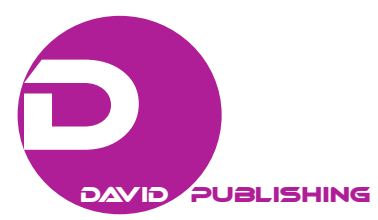

\title{
Small and Medium Enterprises Environment—Case of Albania
}

\author{
Arjona Spahiu \\ Tirana Bank, Tirana, Albania \\ Ana Kapaj \\ Agriculture University of Tirana, Tirana, Albania
}

\begin{abstract}
Small and Medium Enterprises (SMEs) play an important role in all economies and are key generators of employment, earnings, and economic growth stimulators. In Albania, small and medium enterprises represent 99.6 percent of all registered business entities and are the main source in providing employment (Enhancing SME Development in Albania: A Study on Macro-Financial Soundness Indicators, 2011). The aim of this study is to give a short description on the situation of the small and medium enterprises in Albania, giving more focus on the problem faced and the role of the Albanian government on this process. A descriptive analysis is carried out using secondary sources. This study will be a reference for any future study that will be focused on the identification and assessment of factors affecting the SME's performance and the examination of relationship between financial institutions and SMEs growth.
\end{abstract}

Keywords: role, SMEs growth, Albania

\section{Introduction}

Albania has entered a new phase of economic reforms for a better future and the prosperity of the country. The country's development is linked to the strengthening and enhancement of the private sector, which is one of the strongest pillars for ensuring the successful integration of Albania into the European Union.

Small and medium enterprises and financial institutions are vital contributors to the overall performance of an economy. SMEs play a crucial role in developing the economy and in creating employment (Enhancing SME Development in Albania: A Study on Macro-Financial Soundness Indicators, 2011). They not only provide employment and income opportunities to a large number of people, but also are at the forefront of technological innovations and export diversification. Similarly, financial institutions play an indispensable role in firm's growth and thus industry productivity and economic growth.

They provide a sound medium of exchange and facilitate trading; encourage mobilization of resources through savings; allocate resources to activities with the highest returns, monitor investments, and exert corporate governance; and spread risks by offering a diversity of financial instruments. Furthermore, they provide financial assistance to fulfill the varied needs of enterprises.

According to an OECD study on countries that belong to this group, SME's employees are more than half

Arjona Spahiu, M.Sc., Risk Management Department, Tirana Bank, Tirana, Albania.

Ana Kapaj, prof. assc., Dr., Economy and Agrarian Policies Development Department, Agriculture University of Tirana, Tirana, Albania.

Correspondence concerning this article should be addressed to Arjona Spahiu, Risk Management Department, Tirana Bank, Tirana, Albania. 
of the work force, meanwhile in European Union countries, they make up 99 percent of all enterprises. Furthermore, 99 percent of these enterprises in EU countries are micro-firms with less than 10 employees. In Albania, small and medium enterprises represent 99.6 percent of all registered business entities. In 2008, the SME sector provided 72.9 percent of the GDP and employed 71.4 percent of all active work forces. The SME's activities in Albania are focused in the local market and very few work in the export sector. The number of SMEs in Albania that have established joint ventures with foreign partners is minimal.

The term "SMEs" covers a wide range of definitions and measures, varying from country to country and between the sources reporting SME statistics. Although there is no universally agreed definition of SME, some of the commonly used criteria are the number of employees, value of assets, value of sales, and size of capital or turnover. However, the most common basis of defining SMEs is the number of employees (Nugent \& Yhee, 2001).

This study is focused on the description of the SME environment in Albania and their role in economic activity.

\section{Definition of SME}

There is no international definition related to SME. Different country, economic sectors, and authors have usually given different definitions to small and medium enterprises. The most common criteria for the identification of an SME are: the number of employees, turnover level, balance sheet assets, and paid-up capital.

European Commission defines SMEs as enterprises which employ fewer than 250 persons and whose annual turnover does not exceed 43 million euro as shown in Table 1 (Commission Recommendation, 2003).

Table 1

SME Definition of the European Commision

\begin{tabular}{llll}
\hline Enterprises & No. of employees & Annual turnover & Annual balance sheet \\
\hline Micro & $1-9$ employees & Up to 2,000,000 EUR & Up to 2,000,000 EUR \\
Small & $10-49$ employees & Up to 10,000,000 EUR & Up to 10,000,00 EUR \\
Medium & 50-249 employees & Up to 50,000,000 EUR & Up to 43,000,000 EUR \\
\hline
\end{tabular}

In Albania, the identification of SME is regulated with the law No. 10042, date 22.12.2008, article 4 “Amendment of the law No. 8957, date 17.10.2002 for Small and Medium Enterprises" (Official Publication Center, 2010). According to this law, the definition of SMEs is based on the number of the employees and the anual turnover as presented in Table 2:

Table 2

SME Definition According to the Albania's Legislation

\begin{tabular}{lll}
\hline Enterprises & No. of employees & Annual turnover \\
\hline Micro & $1-9$ employees & Up to 10,000,000 ALL \\
Small & $10-49$ employees & $10,000,001-50,000,000$ ALL \\
Medium & $50-249$ employees & $50,000,001-250,000,000$ ALL \\
\hline
\end{tabular}

Source: Albania Legislation.

\section{Environment of SME and Business in Albania}

According to "The global competitiveness report 2013-2014", Albania ranked in the 95th of 148 countries/economies. Albania has lost six places in the ranking since last year. Albania is classified in the group of countries that are in the second stage in development of competitiveness (also it is called "stage of economic 
efficiency incentives”). From 12 pillars taken in analyzed by GCR (Global Competitive Review), Albania ranked better in the health and primary education pillar (5.9 points), followed by macroeconomic environment (4.4 points), goods market efficiency pillar (4.1 points), and job market efficiency (4.3 points).

Referring to the three dimensions of the development (basic requirements, efficiency promoters, and factors of innovation and sophistication), Albania recorded the highest score in the first one with (4.2 points and ranked 94th. But, overall ranking of Albania has declined in all three dimensions and in most of the indicators and sub indicators.

The most problematic factors for doing business according to the report are: access to finance, tax rates, corruption, and tax regulation.

In the regional rankings, Montenegro is in the first place. Albania is ready equal with Bosnia and Herzegovina, leaving behind Serbia with sixpositions as depicted in Figure 1. After many years steady progress, Albania has shown decline in the ranking only last two years, from 2012 to 2013, which can be influenced from the impact of external factors (global economic crisis). One the one hand, increasing competitiveness of the economy in the recent years is due to the measures and reforms taken from the governments; on the other hand, in order to be more competitive, it required an emphasis on the innovation factors, technology developement, further improvement of the infrastructure, and consolidation of the institutions (Business and Investments Development Strategy for Years 2014-2020, 2014).

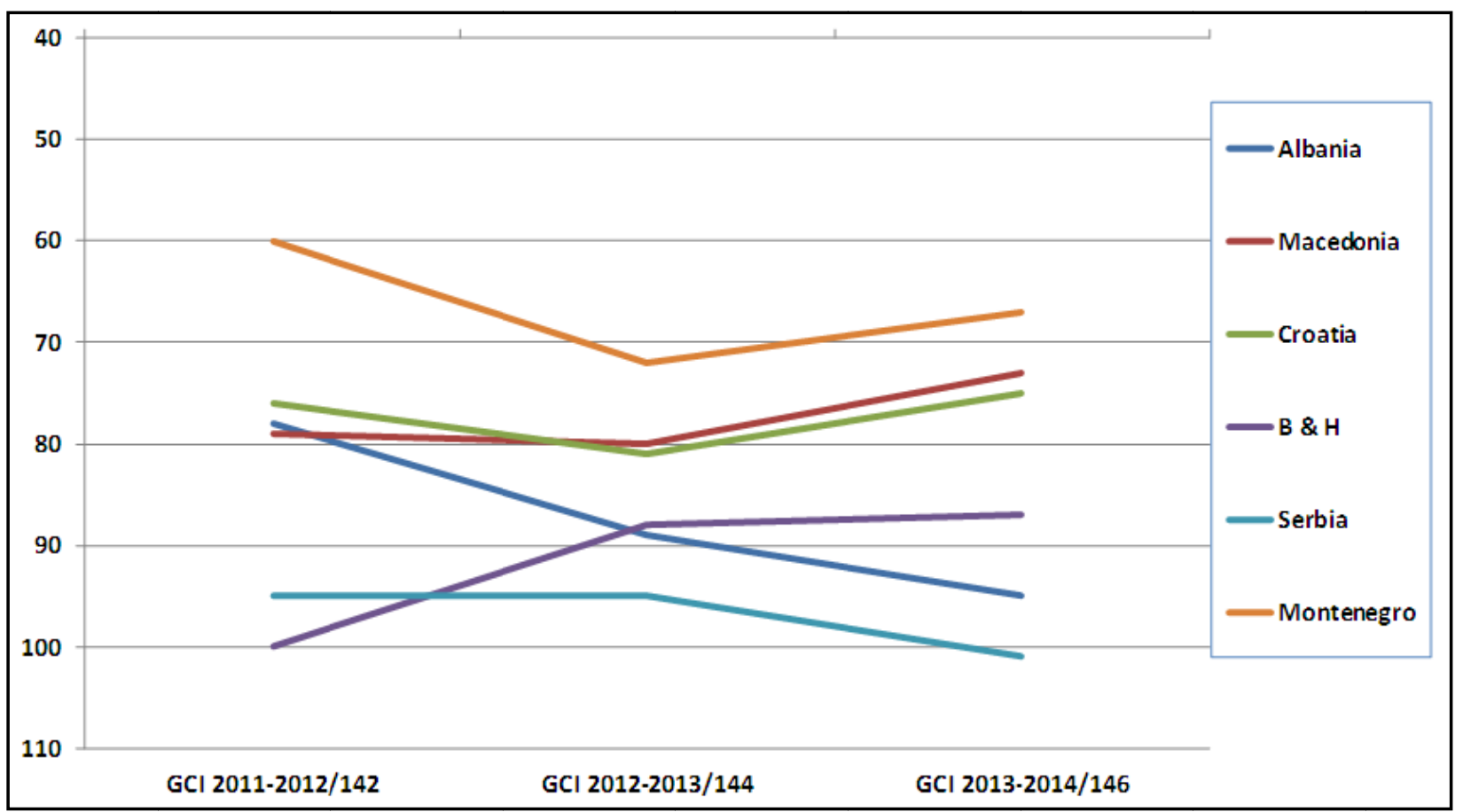

Figure 1. Western Balkan countries ranking according to the Competitiveness Report. Source: Doing Business database 2013.

\section{The Economic Freedom Index}

According to "The Economic Freedom Index 2014", which covers 10 freedoms-from property rights to entrepreneurship-among the 178 countries surveyed worldwide, Albania scored 66.9 points, ranked in the 54th place in world and in 25th place among 43 European countries. Albania is classified in the category of countries 
with moderate economic freedom over the global average (60.3).

Dimensions with the highest ranking of economic freedom remain "fiscal freedom" (92.7 points), followed by "commercial freedom" (87.5) and "monetary freedom" (80.0). Dimensions with lower ranking are the "property rights" (30.0) and "freedom from the corruption" (30.4). The report notes that significant structural reforms have included trade liberalization, privatization, and modernization of the regulatory environment. The judiciary remains subject of the political interference and deep institutional reforms to eradicate corruption and to increase the independence of the judiciary remains critical to ensure greater economic freedom in Albania.

\section{Ease of Doing Business}

According to the World Bank "Doing Business 2013-2014”, Albania is ranked in the 90th place out of 189 countries analyzed as depicted in Figure 2.

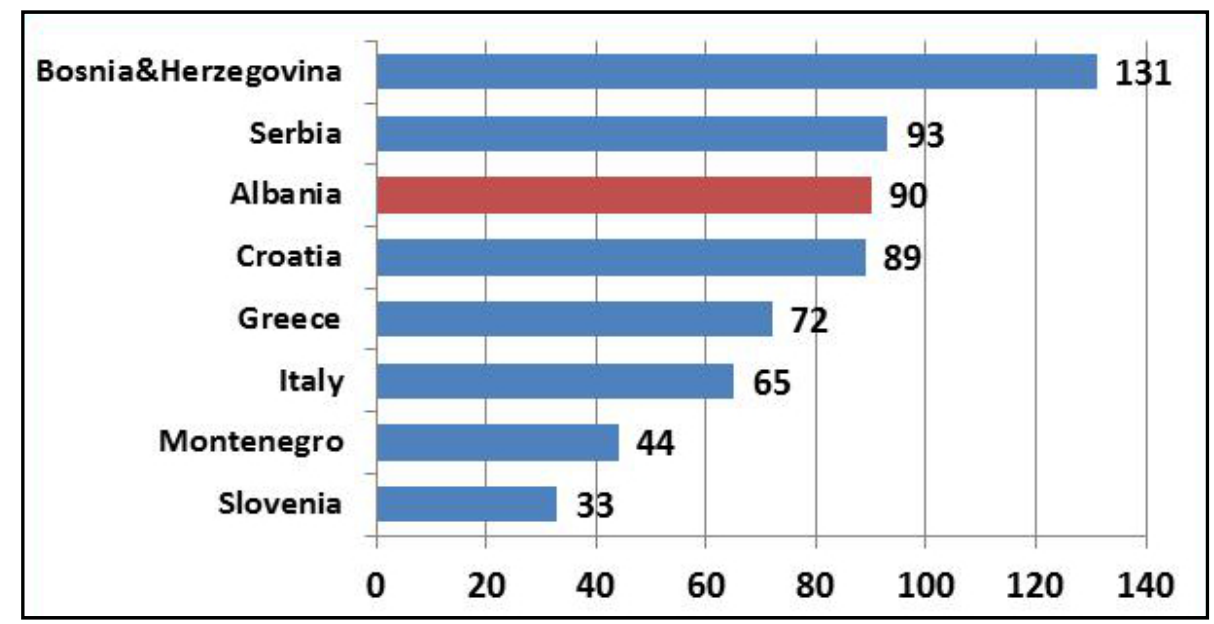

Figure 2. Doing business in the region. Source: Doing Business database 2013.

\section{Economic Activity and the Dynamism of the Albanian SME}

In Albania, small and medium enterprises represent 99.6 percent of all registered business entities. In 2008, the SME sector provided 72.9 percent of the GDP and employed 71.4 percent of all active work forces.

The distinctive characteristic of SME's development in Albania is that services and trades sectors are dominated by micro-enterprises, while industry and construction sectors are dominated by medium enterprises.

Reffering to the information published from the Albania Statistical Institute, the number of active enterprises in the end of 2014 is 112,537. In comparison with the year of 2013, this number has increased with 1,454 active enterprises. The number of new enterprises in 2014 is 17,377 while in 2013 it was 12,131 enterprises. In 2014, enterprise birth rate is 15.4\% from 10.9\% in 2013.

Based on the structure of active enerprenuership in the year 2014, it is noticed that SMEs are mostly dominated by enterprises with one to four employed which constitutes about $90 \%$ of the total number of enterprises as shown in Figure 3. Most of them (69\%) have only one self-employer/employee. Large enterprises with 50 and more employed represent in number (1.3\%) of total active enterprises, but their contribution on employment is very sensitive (50\%).

From the sectional perspective, for the year 2014, the SME sector was composed by producers of services in the level of $84.9 \%$ (trade; transport and storage; accomodation and food services activities; information and communication; and other services) and only $15.1 \%$ from the producers of goods (agriculture, forestry and 
fishing; industry; and construction) (This information is depicted in Figure 4.). The service provider's domination is a common situation in all the regions.

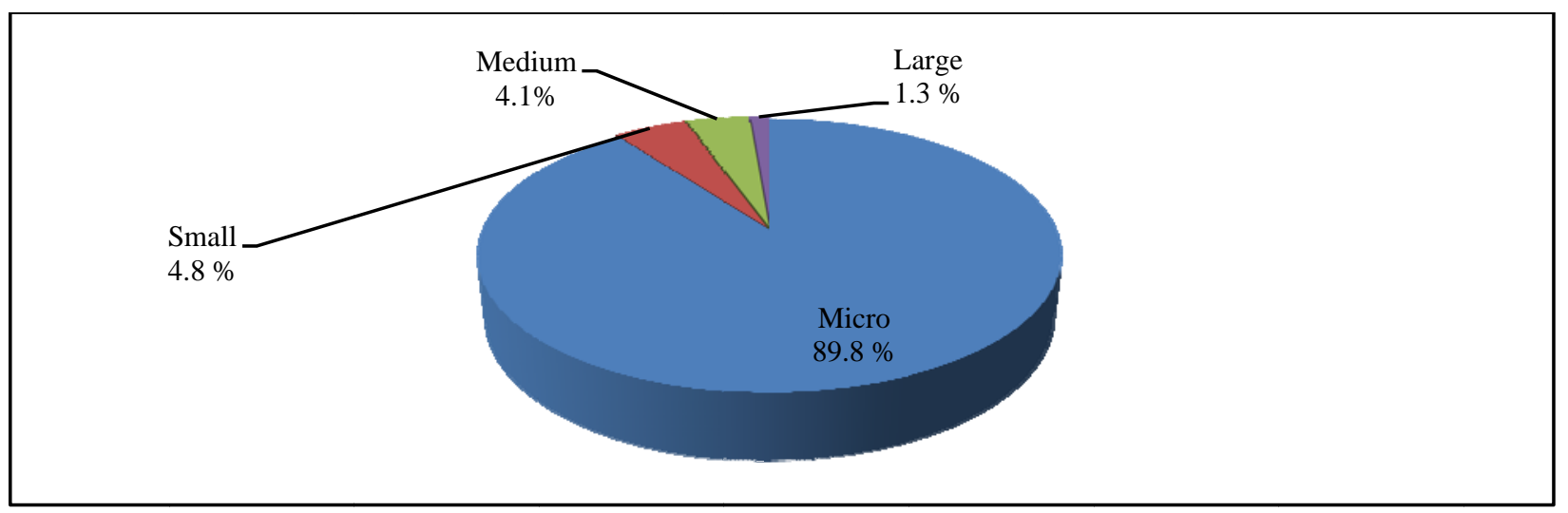

Figure 3. SMEs by size. Source: Business Register 2014-INSTAT.

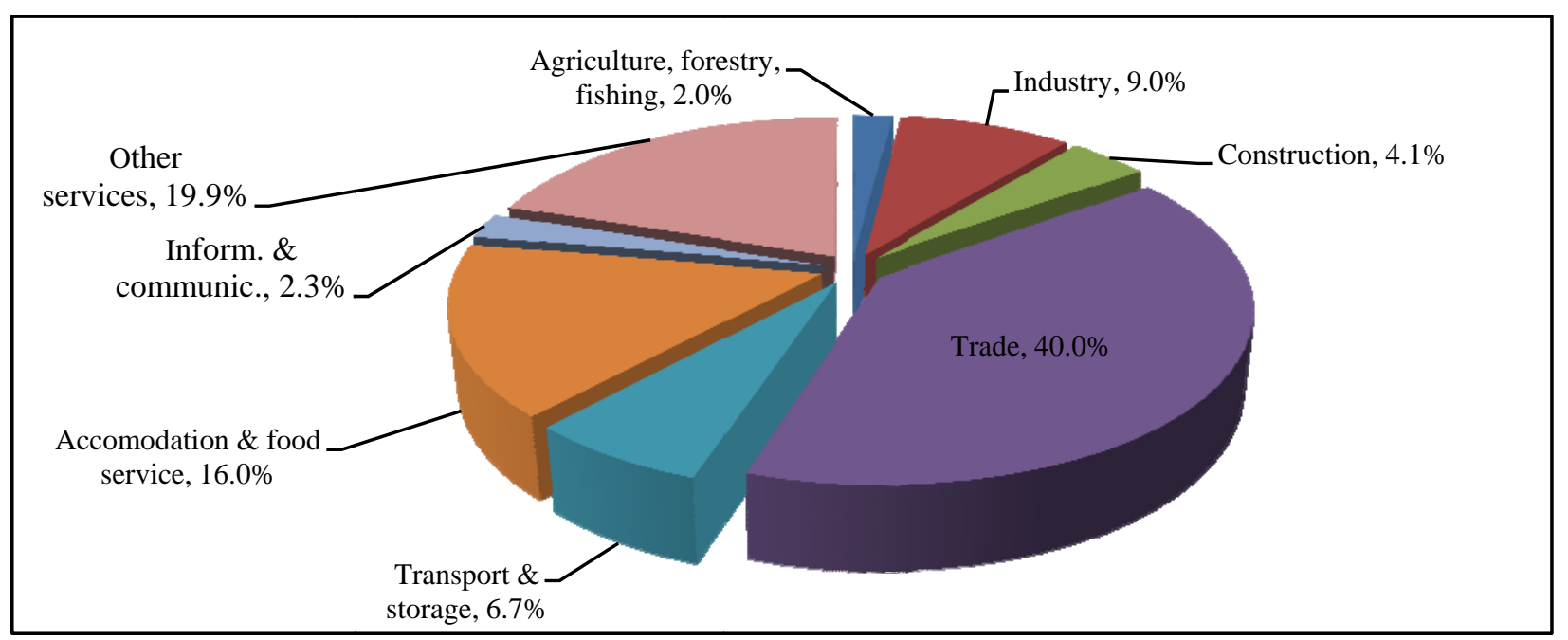

Figure 4. SMEs by economic activity. Source: Business Register 2014-INSTAT.

\section{Coclusions}

Competitiveness of economy is affected by factors at enterprise level as well as overall environment on which the companies operate. The improvement of business environment and the minimization of informality in the business enterprise, coupled with strengthening of the financial sector, could be important elements in enhancing the competitiveness of the economy and provided a strong incentive for strengthening the SME's development.

\section{References}

Business and Investments Development Strategy for Years 2014-2020. (2014). Ministry of Economic Development, Trade and Entrepreneurship, Official Publication Center.

Business Register 2014. (2015). Retrieved from www.instat.gov.al

Commission Recommendation. (2003). Concerning the definition of micro, small and medium-sized enterprises. Official Journal of the European Union.

Enhancing SMEs Development in Albania: A Study on Macro-Financial Soundness Indicators. (2011). Retrieved from www.itacalbania.org 
Nugent, J. B., \& Yhee, S. J. (2001). Small and medium enterprises in Korea: Achievements, constraints and policy issues. World Bank, Washington D.C.

Official Publication Center. (2010). Retrieved from www.qbz.gov.al

The Global Competitiveness Report 2013-2014. (2013). Word Economic Forum. 